\title{
Impact Assessment of Adoption of Improved Varieties of Groundnut and Sesame in North Kordofan State: Sudan
}

\author{
Salih Elagab Elsheikh ${ }^{1}$, Hanadi El Fadil Abdarazig*2, Hamid H Faki \\ ${ }^{1}$ Elobeid Agricultural Research Station, Socio-economics Research Programe, Sudan \\ ${ }^{2}$ Agricultural Economics and Policy Research Centre, Sudan
}

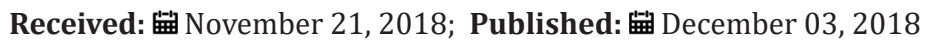

*Corresponding author: Hanadi El Fadil Abdarazig, Agricultural Economics and Policy Research Centre, Shambat, Sudan

\begin{abstract}
This study was carried out with the objective to assessment the impacts of adoption of improved varieties of groundnut and sesame on the farm income of households in three localities of Sheikan, Umrawaba and Elrahad in the North Kordofan State. Data for this study was primarily from farm household surveys conducted in seven seasons (2006/2007 to 2014/2015) in three localities of Shemika, ElRahad and UmRawaba in North Kordofan State. A random sample of 794 households was randomly drawn from different villages in the study area. Multi-stage random approach was adopted. Treatment effect regression was used to assess the impact of adoption of improved varieties in the study area. Analysis was completed using STATA12 and SPSS22 software packages to draw results and test hypotheses. Results show that Adoption degrees of the improved varieties varied considerably from year to year depending on availability and distribution of improved varieties. The productivity of all improved varieties of food and cash crops were higher than the local varieties. Results show that the annual total household expenses of adopters of improved varieties were greater than the non-adopters by $19 \%$. Factors which significantly and positively affected farmers' decision to adoption improved varieties of groundnut were education of respondents $\left(0.414^{* *}\right)$ and male family members $(0.073)$. Income from farm increased by 29876 SDG per year as a result of adoption improved varieties of ground nut. Area of improved varieties would increase by 9.57 Hectare per year as a result of adoption of improved varieties of groundnut. Factors which significantly and positively affected farmers' decision to adoption improved varieties of sesame were male family members $\left(0.058^{*}\right)$ and age of respondents $\left(0.024^{* *}\right)$. Income from farm increased by 7533.7 SDG per year as a result of adoption improved varieties of sesame.
\end{abstract}

\section{Introduction}

There has been much discussion on the need to increase productivity and sustainability in agriculture globally in the medium to long terms, but much less information is available on specific means to achieve this aim. Increasing agricultural productivity is critical to meet expected rising demand and, as such, it is instructive to examine recent performance in cases of modern agricultural technologies [1]. In Sudan, sorghum, millet, groundnut and sesame yields per unit area of land are higher at research level and well managed farms than in typical farmers' fields. The yield gap is mainly attributed to ineffective extension and technology transfer, lack of access to inputs, poor access to finance, and problems related to marketing. The rain-fed farming sector in Kordofan region has been contributing considerably to the country's annual crop production. It produces about $40 \%$ of the total millet production, $15 \%$ of sorghum, $25 \%$ of groundnut, $30 \%$ of sesame, and $5 \%$ of maize. Other crops grown in the region include roselle, cowpea, and cotton.

\section{Problem Statement}

In general, agricultural production and productivity could be increased by allocation of more resources to agriculture and improvement of agricultural technology which requires more investment in education, health and infrastructure. In the context of Sudan profile, various governments have declared a policy aiming at self-sufficiency in food. The means towards achieving this objective has always been an expansion in cultivated area and/or improvement in yield. It is no longer possible to meet the needs of increasing numbers of the world population and to achieve food security objectives by expanding areas under cultivation since the fertile land is not increasing over time. But this problem can only be better solved by increasing agricultural productivity of farm households. Still, achieving agricultural productivity growth will not be possible without developing and disseminating yieldincreasing technologies and application of these technologies by farm households. A main feature of farming in North Kordofan 
is continuous deterioration in the natural resources base and production. Such deterioration has resulted from various influential factors, among them are poor genetic resources, biophysical factors including topography, low rainfall, soil quality, insect, diseases. Adoption studies are required to be conducted in the area but accessed information does not show that such adoption studies have been conducted in North Kordofan state in general and Sheikan, Elrahad and Umrawaba localities, in particular to identify the determinants the impact of adoption of improved varieties on the farm income, this research study was conducted in the study area to fill in this gap by identifying constraints to the adoption decisions and the impacts of adoption on the livelihoods of the adaptors.

\section{Objectives of the Study}

The overall objective of this study is to assess the impacts of adoption improved varieties of groundnut and sesame on the yield and farm income of households. The study also aims to achieve the following specific objectives:

1. To identify and analyze socioeconomic factors that influences the adoption of improved varieties of groundnut and sesame among farmers.

2. To understand the factors that determines the adoption and intensity of use of improved varieties of groundnut and sesame.

3. To study the impact of adoption improved varieties of groundnut and sesame on yield and farm income of households.

\section{Research Hypotheses}

a) Adoption of improved varieties leads to high yields of groundnut and sesame.

b) Improved technologies have positive changes in productivity, and hence improve monetary gross margins and livelihood of the smallholder farmers.

c) Farmers' perception of technology characteristics significantly affects their adoption decision.

d) Adoption of improved crops varieties leads to higher household income and increase farm income of households.

\section{Data Sample Procedures}

\section{The Sampling}

Data for this study comes primarily from farm household survey conducted in three localities: Sheikan, ElRahad and UmRawaba in North Kordofan State. Multi-stage random approach was adopted. The localities were used as a sampling frame. From the three localities we selected nine locality units randomly, from theses nine locality unit eight to twelve villages were randomly selected for conducting interviews for individual households. Accordingly, a sample of 794 households was randomly drawn from different villages in the study area. Selection was structured on the basis of ensuring a representative sample of male and female household heads. Farmer's household heads were interviewed using questionnaire. Analysis was undertaken using STATA12 and SPSS22 software packages according to which results and hypotheses were drawn.

\section{Treatment Effects Regression}

A treatment effect is the average causal effect of a binary $(0-1)$ variable on an outcome variable of scientific or policy interest. The term treatment effect originates in medical literature concerned with the causal effects of binary, yes or no, such as an experimental drug or a new surgical procedure. But the term is now used much more generally. The causal effect of a subsidized training program is probably the mostly widely analyzed treatment effect in economics see, for example, Ashenfelter [2].

The model assumes a treatment $\mathrm{W}$ is binary with two possible states; W (0) and W (1).

For each unit, there are two potential outcomes; Y (0) (the outcome without treatment) and Y (1) (the outcome with treatment). These outcomes can be discrete, continuous, or both.

The gain from treatment is

$$
Y(1)-Y(0)(1)
$$

For a particular unit i, the gain from treatment is

$$
Y i(1)-Y i(0)(2)
$$

If we could observe these gains for a random sample, the problem would be easy: just average the gain across the random sample.

The key problem with this model is that for each unit $\mathrm{i}$, only one of Yi (0) and Yi (1) is observed and in effect, there is a missing data problem. It assumes a random sample of units from the population, but we do not observe both outcomes.

In the treatment effects regression model, there are two parameters of primary interest:

a) The average treatment effect (ATE) which is the expected gain for a randomly selected unit from the population

$$
\text { Tate }=E[Y(1)-Y(0)](3)
$$

b) The average treatment effect on the treated (ATT) is the average gain for those who actually were treated:

$$
\text { Tatt }=E[Y(1)-Y(0) \mid W=1](4)
$$

With heterogeneous treatment effects - that is, when $Y i(1)-Y i(0)$ is not constant the average treatment effect and the average treatment effect on the treated can be very different.

Occasionally it is helpful to define average treatment effects in a sample, for example,

$$
\text { ate }=N^{-1} \Sigma i=1(Y i(1)-Y i(0)(5)
$$

The key assumptions of the treatment effects regression are:

a) Confoundedness rather than assume random assignment for each unit i a random vector representing the population 
distribution of covariates $\mathrm{Xi}$ is drawn. The strongest form of confoundedness is conditional on $\mathrm{X}$, the counterfactual outcomes are independent of W. For units in the subpopulation defined by X = $\mathrm{x}$, assignment of treatments is randomized. (6)

Overlap: for all $\mathrm{x}$ in the support $\mathrm{X}$ of $\mathrm{X}, 0<P(W=1 \mid X=x)<1$

In other words, each unit in the defined population has some chance of being treated and some chance of not being treated. The probability of treatment as a function of $\mathrm{x}$ is known as the propensity score $P(x)=P(W=1 \mid X=x)(7)$

\section{Results and Discussion}

\section{Education level}

Table 1 shows that (43.1\%) of the respondents were literate and this is an advantage for adoption of farm innovations as education has been shown to be a factor in the adoption of high yielding modern farm practices (Obinne, 1991). In other words, the high level of education among the respondents would likely make them more responsive to many agricultural extension programmes and policies. Agwu and Anyanwu (1996) reported that increase in education of farmers positively influences adoption of improved practices.

Table 1: Distribution of respondents according to education levels in Sheikan, Umrawaba and Elrahad

\begin{tabular}{|c|c|c|}
\hline Education level & Frequency & Percentage \\
\hline Illiterate & 336 & 42.3 \\
\hline Khalwa & 116 & 14.6 \\
\hline Primary & 240 & 30.2 \\
\hline Secondary & 99 & 12.5 \\
\hline University & 3 & 0.4 \\
\hline Total & 794 & 100 \\
\hline
\end{tabular}

Source: Field surveys.

\section{Cropped Area, Seeds Utilization and Productivity}

Table 2: Average total owned and cultivated area (ha).

\begin{tabular}{|c|c|c|c|}
\hline Variable & Minimum & Maximum & Mean \\
\hline Owned area (ha) & 0 & 110 & 20.7 \\
\hline Cultivated area (ha) & 0 & 77 & 8.2 \\
\hline $\begin{array}{c}\text { Area cultivated with local } \\
\text { seeds (ha) }\end{array}$ & 0 & 47.8 & 6.44 \\
\hline $\begin{array}{c}\text { Area cultivated with } \\
\text { improved Seeds (ha) }\end{array}$ & 0 & 29.4 & 1.73 \\
\hline
\end{tabular}

Source: Field surveys.

The area allotted to each crop varies with the relative importance of the crop in the area; farmers cultivate different types of food and cash crops. Sorghum (zenari and arfaagadmek) were occupied the large average cultivated area among food crops. Table 2 shows that farmers differed in their owned and cultivated land. Land ownership varies from 0 to 110 ha and the cultivated area ranged from 0 to 77 ha. The average area cultivated with local seeds was higher than the area cultivated with improved seeds and this indicates that there was low degree of adoption of improved varieties (21\%) among farmers in Sheikan, Umrawaba and Elrahad localities (Figure 1).

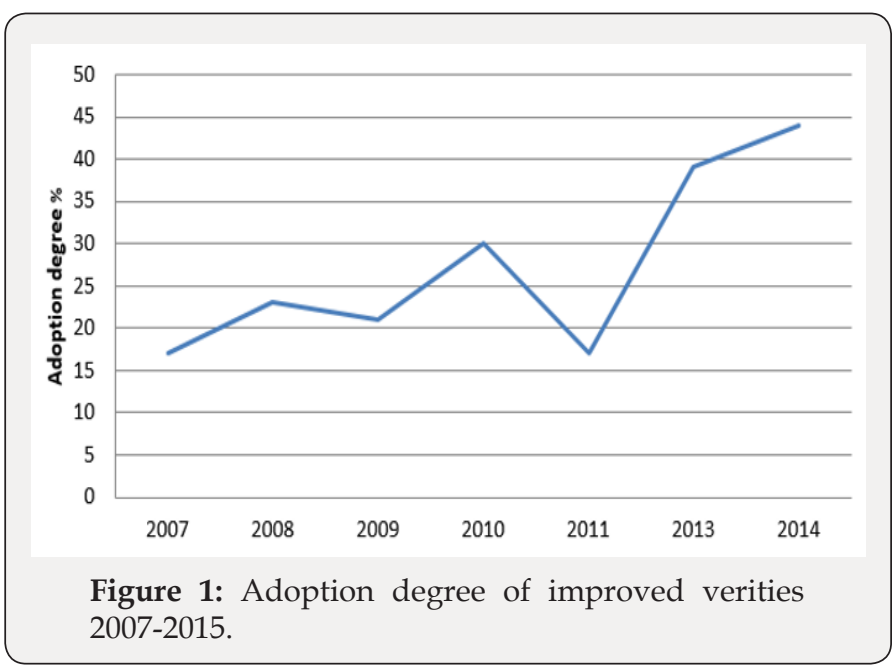

\section{Crops Cultivated Areas}

The proportion of acreage allotted to each of the crop varies with the relative importance of the crop in the area, thus different parts of the localities grow different combinations of crops. Thus, millet and sorghum as main staple food crops in the area, occupy most of the cultivated area in most of the localities. As shown in Table 3, the largest average cultivated area per household was the sesame improved variety Bromo (6.25 Ha), followed by sorghum (Arfaa gadamek (2.65 Ha), Zenari (2.65 $\mathrm{Ha}$ ) and millet Dembi (2.5 Ha) in the three localities of study area. Table 3 reveals that the average harvested area was less than the average cultivated area for all food and cash crops (Millet, Sorghum, Groundnut and Sesame varieties). Productivity of all improved varieties of food and cash crops was greater than that of the local varieties (Table 3). Yield is a primary measure of seed performance Shiyani et al. [3] Kristjanson et al. [4] Crop varieties that have high capacity to yield high stand better chances of being adopted as well as being used intensively by farmers. The higher the yield from a crop variety, the higher will be the marginal returns to investment in seeds, and hence higher income. This forms an incentive for expanding land area under improved varieties. This result agrees with Asante et al. [5] adoption of improved technologies is therefore expected to enhance productivity and consequently increase incomes, reduce poverty and consequently ensure equity among beneficiaries. As a result of low improved technologies employed by most small-scale farmers, the desirable level of increase in agricultural productivity has been difficult to achieve Federal Republic of Nigeria [6]. 
Table 3: Distribution of respondents according to average area grown, production and productivity/Ha of the main food and cash crops.

\begin{tabular}{|c|c|c|c|c|c|}
\hline Crop & Variety & Area grown (Ha) & Area harvested (Ha) & Production /kg & Productivity (Kg/Ha) \\
\hline \multicolumn{6}{|c|}{ Millet } \\
\hline & Ashana & 1.32 & 1.17 & 227 & 194 \\
\hline & Dembi & 2.5 & 2.06 & 372 & 180 \\
\hline \multicolumn{6}{|c|}{ Sorghum } \\
\hline & Arfaa gadamek & 2.65 & 1.76 & 531 & 302 \\
\hline & Aroose elremal & 1.31 & 1.1 & 399 & 362 \\
\hline & Wad ahmed & 2.35 & 2.05 & 771 & 376 \\
\hline & Urwasha & 1.32 & 1.17 & 329 & 281 \\
\hline & Botana & 2.05 & 2.05 & 703 & 342 \\
\hline & Gadem elhamam & 2.5 & 1.76 & 531 & 302 \\
\hline & Zenari & 2.65 & 2.57 & 527 & 205 \\
\hline \multicolumn{6}{|c|}{ Groundnut } \\
\hline & Sodri & 1.1 & 0.88 & 549 & 623 \\
\hline & Gebaish & 1.69 & 1.47 & 906 & 616 \\
\hline & Barberton & 1.03 & 0.88 & 372 & 422 \\
\hline \multicolumn{6}{|c|}{ Sesame } \\
\hline & Obeid 1 & 3.01 & 2.65 & 482 & 182 \\
\hline & Bromo & 6.25 & 5.51 & 777 & 141 \\
\hline & Herhri & 4.11 & 3.75 & 443 & 118 \\
\hline
\end{tabular}

Source: Field survey.

Income Sources and Expenditures of Adopters and Non-Adopters

Table 4 shows that the annual total household income of adopters of improved varieties was greater than that of nonadopters by $22 \%$, while the average annual total household income per capita was (SDG 20967) and (SDG 17180) for adopters and non-adopters, respectively. This result indicates that adoption of improved varieties will increase the farm income (Table 4). This

finding agreed with, Bourdillon et al. [7] who observed that the adoption of improved maize varieties increased the crop incomes of adopters only modestly in Zimbabwe. Table 5 shows that the annual total household expenses of adopters of improved varieties was greater than the non-adopters by $19 \%$, while the average annual total household expenses per capita was (SDG 67268) and (SDG 56659) for adopters and non-adopters, respectively. This result indicates that adoption of improved varieties will increase the average household expenses (Table 5).

Table 4: Distribution of respondents according to annual sources of income per SDG.

\begin{tabular}{|c|c|c|c|c|}
\hline Source of income & Adopters & Non adopters & $\begin{array}{c}\text { All increase of adopter to } \\
\text { non-adopter }\end{array}$ \\
\hline Farm income (SDG) & 3997 & 2718 & 3306 \\
\hline Trade income(SDG) & 3283 & 3180 & 3236 \\
\hline $\begin{array}{c}\text { Agricultural labor } \\
\text { income(SDG) }\end{array}$ & 3281 & 2367 & 2643 & 39 \\
\hline Livestock income (SDG) & 3074 & 1972 & 2502 & 59 \\
\hline Free works income (SDG) & 2486 & 2661 & 2583 & -6 \\
\hline Migration (SDG) & 1418 & 912 & 1188 & 55 \\
\hline Gifts (SDG) & 1250 & 1470 & 1354 & -15 \\
\hline Sons transfers (SDG) & 2178 & 1900 & 2000 & 15 \\
\hline Total & 20967 & 17180 & 18812 & 22 \\
\hline
\end{tabular}

Source: Field survey. 
Table 5: Distribution of respondents according to annual household expenses (SDG).

\begin{tabular}{|c|c|c|c|c|}
\hline Expenses & Adopters & $\begin{array}{c}\text { Non } \\
\text { adopters }\end{array}$ & All & $\begin{array}{c}\text { \% increase } \\
\text { of adopter } \\
\text { over non } \\
\text { adopter }\end{array}$ \\
\hline Consumption expenses & 30840 & 26729 & 28365 & 15 \\
\hline Drinking water & 3245 & 2805 & 2978 & 16 \\
\hline Medical expenses & 968 & 1547 & 1318 & -37 \\
\hline Education expenses & 2447 & 1324 & 1796 & 84 \\
\hline Electronic expenses & 3810 & 525 & 3262 & 625 \\
\hline Building & 4009 & 3085 & 3406 & 30 \\
\hline Agricultural inputs & 712 & 404 & 529 & 67 \\
\hline Rented labor & 6324 & 2253 & 4797 & 180 \\
\hline Animal feeding & 3462 & 4043 & 3758 & -14 \\
\hline Marriage expenses & 8176 & 10958 & 9981 & -25 \\
\hline Social occasions & 1676 & 1570 & 1613 & 7 \\
\hline Clothing & 1479 & 1356 & 1413 & 10 \\
\hline Electricity & 120 & 160 & 140 & -25 \\
\hline Total expenses & 67268 & 56659 & 63356 & $19 \%$ \\
\hline
\end{tabular}

Source: Field survey.

\section{Varietal Characteristics}

The farmers state that the improved varieties of groundnut and sesame have better characters than the local varieties (Tables 6 \& 7).

Table 6: Groundnut characteristics in Sheikan, ElRahad and Umrawaba localities. 2007/2015.

\begin{tabular}{|c|c|c|c|c|}
\hline Don't know & $\begin{array}{c}\text { Improved } \\
\text { variety }\end{array}$ & $\begin{array}{c}\text { Local } \\
\text { variety }\end{array}$ & Indifferent & Don't know \\
\hline $\begin{array}{c}\text { Drought } \\
\text { resistance }\end{array}$ & 84.6 & 12.4 & 1.5 & 1.5 \\
\hline Pests resistance & 80.2 & 12.3 & 6 & 1.5 \\
\hline $\begin{array}{c}\text { Diseases } \\
\text { resistance }\end{array}$ & 79.9 & 11.8 & 6.5 & 0.3 \\
\hline $\begin{array}{c}\text { Production in } \\
\text { hard conditions }\end{array}$ & 86.6 & 11.1 & 1 & 1.3 \\
\hline Early maturing & 86.5 & 10 & 2.5 & 1 \\
\hline Easy to harvest & 77 & 9.9 & 12.5 & 0.5 \\
\hline Seeds size & 85.8 & 10.4 & 3.3 & 0.5 \\
\hline $\begin{array}{c}\text { High } \\
\text { Productivity }\end{array}$ & 87.4 & 10.8 & 1 & 0.8 \\
\hline Better Taste & 72.6 & 11.9 & 14.5 & 1 \\
\hline Best Colour & 72.3 & 11.2 & 15.3 & 1.3 \\
\hline \begin{tabular}{c} 
High Price \\
\hline $\begin{array}{c}\text { Tillers } \\
\text { production }\end{array}$
\end{tabular} & 79.7 & 9.9 & 9.9 & 0.5 \\
\hline
\end{tabular}

Source: Field surveys, 2007-2015.
Table 7: Sesame characteristics in Sheikan, Elrahad and Umrawaba localities. 2007/2015.

\begin{tabular}{|c|c|c|c|c|}
\hline Characters & $\begin{array}{c}\text { Improved } \\
\text { variety }\end{array}$ & $\begin{array}{c}\text { Local } \\
\text { variety }\end{array}$ & Indifferent & Don't know \\
\hline $\begin{array}{c}\text { Drought } \\
\text { resistance }\end{array}$ & 82.8 & 14.4 & 1.5 & 1.3 \\
\hline $\begin{array}{c}\text { Pests } \\
\text { resistance }\end{array}$ & 79.3 & 14.8 & 4.4 & 1.6 \\
\hline $\begin{array}{c}\text { Diseases } \\
\text { resistance }\end{array}$ & 79.3 & 14.7 & 4.5 & 1.6 \\
\hline $\begin{array}{c}\text { Production } \\
\text { in hard } \\
\text { conditions }\end{array}$ & 82.4 & 14.8 & 1.8 & 1 \\
\hline $\begin{array}{c}\text { Early } \\
\text { maturing }\end{array}$ & 86 & 11.9 & 1.3 & 0.8 \\
\hline $\begin{array}{c}\text { Easy to } \\
\text { harvest }\end{array}$ & 80.1 & 13.2 & 5.9 & 0.8 \\
\hline $\begin{array}{c}\text { Large Seeds } \\
\text { size }\end{array}$ & 78.5 & 16.8 & 3.9 & 0.8 \\
\hline $\begin{array}{c}\text { High } \\
\text { Productivity }\end{array}$ & 86.3 & 11.9 & 0.8 & 1.1 \\
\hline Better Taste & 80.3 & 13.5 & 4.9 & 1.3 \\
\hline Best Colour & 87 & 10.9 & 1.6 & 0.5 \\
\hline High Price & 85 & 10.1 & 4.4 & 0.5 \\
\hline $\begin{array}{c}\text { Tillers } \\
\text { production }\end{array}$ & 79 & 17.4 & 1.7 & 2 \\
\hline
\end{tabular}

Source: Field surveys, 2007-2015.

\section{Impact of Using Improved Varieties of Groundnut on Farm Income}

The treatment effects regression is used to assess the impacts of using improved varieties of groundnut on farm income, using improved varieties is the treatment in the first equation of this model because it is the main component of the package [6]. In the first step, using improved varieties is regressed against different variables which affect the likelihood to adopt improved varieties of groundnut which is used to estimate the impacts in the second step of the treatment effects model (Table 8). For the impacts of adoption of improved varieties of groundnut on farm income, the most important factors which increase the likelihood to adopt improved varieties of groundnut was attending training (1.4701***), number of males in the family (0.0962), education (0.2492), age (0.0073) and total area grown (0.0086). The effect of variety in the outcome equation (farm income) was significant at the 0.01 level. Income from farm increased by SDG 29876 per year as a result of adoption of groundnut improved varieties. Sex of household head (11671*), farmers' experience (353), participation male labor (944) were the most important factors which increased farm income, whereas farmers old age $\left(-694^{* *}\right)$ lead to decreased farm income (Table 8). For the impacts of adoption improved varieties of groundnut on area of improved varieties, the most important factors which increase the likelihood to adopt improved varieties of groundnut were attending training, numbers of males and female's family members, 
farmers experience, whereas knowledge of cultural operations, poverty and consequently ensure equity among beneficiaries family labor, hired labor and sex of farmers are inversely related to adoption of improved variety of groundnut. Those results agreed with that adoption of improved technologies are therefore expected Asante et al. [5] Area of improved varieties would increase by 9.57 hectare per year as a result of adoption of improved varieties of groundnut. The effect of variety in the outcome equation (area of to enhance productivity and consequently increase incomes, reduce improved varieties) was significant at 0.05 level (Table 9).

Table 8: Estimates of the treatment effects regression on income for groundnut.

\begin{tabular}{|c|c|c|c|c|}
\hline & \multicolumn{2}{|c|}{ Variety } & \multicolumn{2}{|c|}{ Income } \\
\hline & Coefficient & SE & coefficient & SE \\
\hline Farming experience (years) & & & 353 & 279 \\
\hline Education & 0.2492 & 0.9807 & -4162 & 5345 \\
\hline Males family members & 0.0962 & 0.1104 & -212 & 1257 \\
\hline Females family members & & & -766 & 966 \\
\hline Participation of male's labor & & & 944 & 1665 \\
\hline Age of $\mathrm{HH}$ & 0.0073 & 0.017 & $-695^{* *}$ & 323 \\
\hline Total grown area & 0.0086 & 0.007 & & \\
\hline Sex of HH & -0.6617 & 0.5919 & $11671^{*}$ & 6823 \\
\hline Training & $1.4701^{* * *}$ & 0.4445 & & \\
\hline Adoption improved variety & & & $29876^{* * *}$ & 9127 \\
\hline Constant & -1.5206 & 1.1458 & 21008 & 12994 \\
\hline Wald chi2 & & & 20.39 & \\
\hline Prob $<$ chi2 & & & 0.06 & \\
\hline Rho & & & -1 & \\
\hline Sigma & & & 16414.72 & \\
\hline Number of observations & & & 74 & \\
\hline lambda & -17838.3 & 5163.307 & $0.001^{* * *}$ & \\
\hline
\end{tabular}

Symbols *** and *** indicate significant differences at 0.1, 0.05 and 0.01 levels of significance, respectively.

Table 9: Estimates of the treatment effects regression on area of improved varieties for Groundnut.

\begin{tabular}{|c|c|c|c|c|}
\hline & \multicolumn{2}{|c|}{ Variety } & \multicolumn{2}{|c|}{ Area improves } \\
\hline & varieties & SE & coefficient & SE \\
\hline & Coefficient & SE & coefficient & SE \\
\hline Farming experience (years) & 0.016 & 0.04 & 0.048 & 0.144 \\
\hline Education & 0.094 & 0.563 & $-6.079^{* * *}$ & 2.178 \\
\hline Hired labor & -0.625 & 0.492 & & \\
\hline Males family members & 0.053 & 0.141 & $1.394^{* * *}$ & 0.519 \\
\hline Female's family members & 0.214 & 0.149 & -0.046 & 0.648 \\
\hline Participation of male's labor & & & -0.44 & 0.868 \\
\hline Participation of female's labor & & & -0.478 & 1.1 \\
\hline Use of improved varieties & & & 0.721 & 1.964 \\
\hline Age of $\mathrm{HH}$ & 0.001 & 0.043 & -0.158 & 0.157 \\
\hline Sex of $\mathrm{HH}$ & -0.877 & 0.728 & 1.557 & 2.797 \\
\hline Family labor & -4.743 & 455.87 & & \\
\hline Knowledge cultural operations & $-1.083^{* *}$ & 0.548 & & \\
\hline Training & 0.641 & 0.592 & 0.028 & 2.891 \\
\hline Agric-income & 2.3 & 0 & & \\
\hline Adoption of improved variety & & & $9.57^{* * *}$ & 4.698 \\
\hline Constant & $5.737^{* * *}$ & 455.87 & 3.417 & 6.531 \\
\hline Prob $<$ chi 2 & & & $0.0000^{* * *}$ & \\
\hline
\end{tabular}




\begin{tabular}{|c|c|c|c|c|}
\hline Rho & & & -1 & \\
\hline Sigma & & & 6.372245 & \\
\hline Number of observations & & & 69 & \\
\hline lambda & -6.806121 & 2.553878 & $0.008^{* * *}$ & \\
\hline
\end{tabular}

Symbols *,** and *** indicate significant differences at 0.1, 0.05 and 0.01 levels of significance, respectively.

\section{Impact of Using Improved Varieties of Sesame on Farm} Income

The treatment effects regression was used to assess the impacts of using of improved varieties of sesame on farm income, using improved varieties is the treatment used in the first equation of this $[7,8]$. In the first step using improved varieties is regressed against different variables which affect the likelihood to adopt improved varieties of sesame which was used to estimate the impacts in the second step of the treatment effects model. The most important factors which increase the likelihood to adopt improved varieties of sesame were area grown by improved varieties $\left(0.513^{* * *}\right)$ and total farm income $\left(0.0001^{* * *}\right)$ whereas knowledge of cultural operations $\left(-0.803^{* *}\right)$ was inversely related to variety adoption (Table 10). The correlation coefficient between variety and farm income was 0.39 and the effect of variety in the outcome equation (farm income) was significant at 0.01 levels. This result disagrees with what was reported by Shiyani et al. [3] that small farmers, in comparison to large farmers, adopt improved technologies at a faster rate if additional gains are substantial. This is likely due to two reasons. First, small farmers live at subsistence level that attracts them to adopt improved varieties which give better yields, earn more income and thereby helping in raising their standard of living. Secondly, limited availability of improved seeds might compel large farmers to partly continue for producing alternatives. Income from farm increased by 7533.7 SDG per year as a result of adopting of sesame improved varieties. The number of males in the family (909*) and attending training (8086.90***) were the most important factors which increased farm income, whereas higher farmers age $\left(-236.95^{* *}\right)$ and larger numbers of females in the household $\left(-1050^{*}\right)$ decreased farm income (Table 10). This result agreed with report that adoption of improved technologies is expected to enhance productivity and consequently increase incomes, reduce poverty and consequently ensure equity among beneficiaries. A negative relationship between age and likelihood of variety adoption exists due to younger farmers being more likely to be willing to be innovating; older farmers may be less willing to adopt new verities given the heavy labor requirements [8]. These results back up the result of Neil and Lee [8] that young farmers are more likely to adopt a new For the impacts on area of improved varieties, the most important factors which increase the likelihood to adopt improved varieties of sesame were total area grown $\left(0.513^{* * *}\right)$ and total farm income $\left(0.000^{* * *}\right)$, whereas knowledge of cultural operations $\left(-0.803^{* * *}\right)$ was inversely related to variety adoption. The area of improved varieties increased by 5.57 hectare per year as a result of adoption of sesame improved varieties (Table 11).

Table 10: Estimates of the treatment effects regression on farm income for sesame.

\begin{tabular}{|c|c|c|c|c|}
\hline & \multicolumn{2}{|c|}{ Variety } & \multicolumn{2}{|c|}{ Income } \\
\hline & Coefficient & SE & coefficient & SE \\
\hline Farming experience (years) & -0.027 & 0.023 & 109.51 & 116.08 \\
\hline Education & -0.311 & 0.411 & -657.95 & 1920 \\
\hline Knowledge cultural operations & $-0.803^{* *}$ & 0.367 & & \\
\hline Males family members & -0.07 & 0.108 & $909^{*}$ & 548.75 \\
\hline Females family members & -0.021 & 0.105 & $-1050 *$ & 580.13 \\
\hline Males Family labors & & & 901.66 & 863 \\
\hline Females Family labors & & & 149.26 & 874.48 \\
\hline children Family labors & & & -2022 & 1571 \\
\hline Age of $\mathrm{HH}$ & 0.026 & 0.021 & $-236.95^{* *}$ & 109.78 \\
\hline Total grown area & & & 43.2 & 41.91 \\
\hline Area grown improved seeds & $0.513^{* * *}$ & 0.09 & & \\
\hline Sex of HH & -0.3835 & 0.439 & 3369.3 & 2378.59 \\
\hline Family labor & -0.304 & 0.94 & & \\
\hline Training & -0.34 & 0.499 & $8086.90^{* * *}$ & 2274 \\
\hline Agricultural income & $0.0001^{* * *}$ & 0.0001 & & \\
\hline Adoption of improved variety & & & $7533.7^{* * *}$ & 2279.77 \\
\hline Constant & 0.25 & 1.341 & $8340^{*}$ & 4195 \\
\hline Prob $<$ chi2 & & & $0.0000^{* * *}$ & \\
\hline
\end{tabular}




\begin{tabular}{|c|c|c|c|}
\hline Rho & & & -0.39108 \\
\hline Sigma & & & 9344.0439 \\
\hline Number of observations & & & 161 \\
\hline lambda & -3654.23 & 1798.904 & 0.042 \\
\hline
\end{tabular}

Table 11: Estimates of the treatment effects regression on area of improved varieties for sesame.

\begin{tabular}{|c|c|c|c|c|}
\hline & \multicolumn{2}{|c|}{ Variety } & \multicolumn{2}{|c|}{ Area of improved variety } \\
\hline & Coefficient & SE & coefficient & SE \\
\hline Farming experience (years) & -0.027 & 0.023 & 0.076 & 0.053 \\
\hline Education & -0.311 & 0.411 & -1.183 & 0.878 \\
\hline Knowledge cultural operations & -0.803 & 0.367 & & \\
\hline Family size male & -0.07 & 0.108 & $0.688^{* * *}$ & 0.249 \\
\hline Family size female & -0.021 & 0.105 & 0.003 & 0.262 \\
\hline Participation male labor & & & -0.557 & 0.362 \\
\hline Participation female labor & & & -0.223 & 0.363 \\
\hline Participation children labor & & & 0.194 & 0.641 \\
\hline Age of $\mathrm{HH}$ & 0.026 & 0.021 & $-.084^{*}$ & 0.05 \\
\hline Total grown area & & & $0.085^{* * *}$ & 0.016 \\
\hline Area grown improved seeds & $0.513^{* * *}$ & 0.09 & & \\
\hline Sex of HH & -0.3835 & 0.4395 & -0.131 & 1.088 \\
\hline Family labor & -0.304 & 0.496 & & \\
\hline Knowledge cultural operations & $-0.803^{* * *}$ & 0.367 & & \\
\hline Training & -0.034 & 0.499 & 1.068 & 1.04 \\
\hline Farm -income & $0.000^{* * *}$ & 0 & & \\
\hline Adoption of improved variety & & & $5.5757^{* * *}$ & 1.031 \\
\hline Constant & 0.2507 & 1.341 & -0.0656 & 1.907 \\
\hline Prob $<$ chi 2 & & & 0 & \\
\hline Rho & & & -0.91247 & \\
\hline Sigma & & & 4.2907393 & \\
\hline Number of observations & & & 161 & \\
\hline lambda & -3.91518 & 0.689036 & 0 & \\
\hline
\end{tabular}

Symbols *** and *** indicate significant differences at $0.1,0.05$ and 0.01 levels of significance, respectively.

\section{References}

1. FAO (2011) The state of food and Agriculture, Women in agriculture, ISSN 0081-4539 FAO (2012) OECD-FAO Agricultural Outlook, 20122021.

2. Ashenfelter O (1978) Estimating the effect of training programs on earnings. Review of Economics and Statistics 60(1): 47-57.

3. Shiyani RL, Joshi PK, Asokam M, Bantilan MCS (2002) Adoption of improved Chickpea Varieties: Krishak Bharati Cooperative (KRIBHCO) Experience in tribal region of Gujurat, India. Agricultural Economics 27(1): 33-39.

4. Kristjanson P, Okeke T, Tarawali S, Singh B, Manyong VM, et al. (2005) Farmers' perception of benefits and factors affecting the adoption of improved dual purpose cowpea in the dry savannahs of Nigeria. Agricultural Economics 32(2005): 195-210.
5. Asante EG, Appiah MR, Ofori Frimpong K, Afrifa AA (2004) The economics of fertilizer use on some peasant cocoa farms in Ghana. Ghana Journal of Agricultural Science 33(2): 183-190.

6. Federal Republic of Nigeria (1990) The Planning Office, Federal Ministry of Budgeting and Planning. First National Rolling Plan 1990-1992. 1 Lagos pp. 71.

7. Bourdillon Michael, Hebinck Paul, Hoddinott John, Kinsey Bill, et al. (2002) Assessing the Impact of HYV Maize in Resettlement Areas of Zimbabwe. Discussion Paper 161 Washington DC: International Food Policy Research Institute.

8. Neil SP, DR Lee (1999) Explaining the adoption and disadoption of sustainable agriculture: the case of cover crops in Northern Honduras. Dept. of Agriculture, Resource and Managerial Economics. Cornell University. Working paper no, pp. 31. 
(c) This work is licensed under Creative

To Submit Your Article Click Here: Submit Article

DOI: 10.32474/CIACR.2018.05.000218

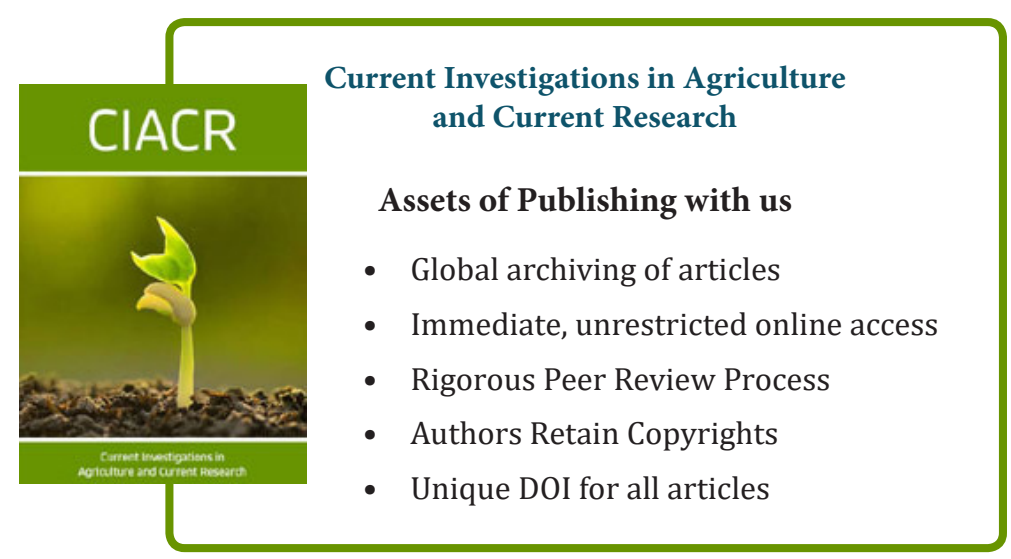

